\title{
Toward a standardised protocol for the stable isotope analysis of scleractinian corals
}

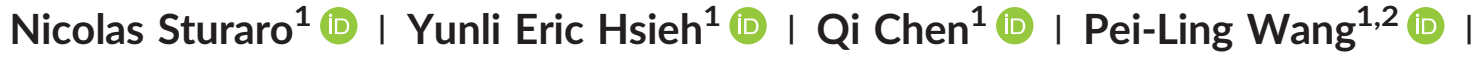 \\ Vianney Denis ${ }^{1}$
}

${ }^{1}$ Institute of Oceanography, National Taiwan University, Taipei, Taiwan

${ }^{2}$ Research Center for Future Earth, National Taiwan University, Taipei, Taiwan

\section{Correspondence}

V. Denis, Institute of Oceanography, National Taiwan University, Taipei, Taiwan.

Email: vianney.denis@gmail.com

\section{Present address}

N. Sturaro, Laboratory of Oceanology, Freshwater and Oceanic Sciences Unit of Research (FOCUS), University of Liège, Liège, Belgium.

Funding information

Ministry of Science and Technology (MOST, Taiwan), Grant/Award Numbers: 104-2611M-002-020-MY2, 106-2611-M-002-008 and 107-2611-M-002-011; National Taiwan University (NTU, Taiwan), Grant/Award Number: 106R4000; Ministry Of Education (MOE, Taiwan), Grant/Award Number: 108L901002
Rationale: The stable isotope analysis of carbon and nitrogen is a powerful tool in many ecological studies, but different sample treatments may affect stable isotope ratios and hamper comparisons among studies. The goal of this study was to determine whether treatments that are commonly used to prepare scleractinian coral samples for stable isotope analysis yield different $\delta^{15} \mathrm{~N}$ and $\delta^{13} \mathrm{C}$ values, and to provide guidelines toward a standardised protocol.

Methods: The animal tissues and Symbiodiniaceae of two symbiotic scleractinian coral species (Stylophora pistillata and Porites lutea) were divided into subsamples to test the effects of the drying method, lipid extraction, acidification treatment and water washing. All the subsamples were analysed for their $\delta^{15} \mathrm{~N}$ and $\delta^{13} \mathrm{C}$ values, using continuous flow elemental analyser/isotope ratio mass spectrometry.

Results: The drying method and lipid extraction treatment had no substantial effects on the $\delta^{15} \mathrm{~N}$ and $\delta^{13} \mathrm{C}$ values of Symbiodiniaceae and animal tissues. Acid treatment did cause significant differences in $\delta^{13} \mathrm{C}$ values (mean differences $\leq 0.5 \%$, with individual samples becoming up to $2.0 \%$ o more negative), whereas no ecologically significant differences were observed in $\delta^{15} \mathrm{~N}$ values. Animal tissue $\delta^{13} \mathrm{C}$ values may vary depending on whether samples are washed or not.

Conclusions: To move towards a standardised protocol in coral research, we recommend using an available drying method (as they are equally acceptable) for the stable isotope analysis of scleractinian corals, examining the need for lipid extraction on a case-by-case basis, performing a direct acidification of Symbiodiniaceae and animal tissues, and avoiding washing animal tissue with distilled water.

\section{1 | INTRODUCTION}

Stable isotope analysis (SIA) has allowed ecologists to identify trophic relationships in a wide variety of ecosystems and describe the structure of marine food webs. ${ }^{1-3}$ In tropical coral reef habitats, many studies have examined the stable isotope compositions of scleractinian coral skeletal material, ${ }^{4-9}$ while fewer have investigated in situ natural variations in stable isotopes in coral host tissues and their associated Symbiodiniaceae. ${ }^{10-15}$ These studies have increased our understanding of the effects of environmental factors (such as depth, light, and turbidity) on the trophic status of corals, the feeding relationships of symbiotic organisms, and the energy sources used. Investigations of potential energy sources (e.g., resource availability in the reef water column and across environmental gradients) are critical when attempting to characterise the trophic status of corals. ${ }^{15,16}$

Carbon and nitrogen stable isotopes are the most commonly used food web tracers in marine ecology, especially in coral studies. ${ }^{17-19}$ Carbon stable isotope ratios $\left({ }^{13} \mathrm{C} /{ }^{12} \mathrm{C}\right.$, expressed as $\delta^{13} \mathrm{C}$ values in per mil notation) are used to track the origin of carbon in the $\operatorname{diet}^{20}$ and elucidate whether coral animal tissue derives more carbon from 
allochthonous sources (e.g., zooplankton) than from Symbiodiniaceae photosynthesis (i.e., photoassimilate translocation). In contrast, nitrogen stable isotope ratios $\left({ }^{15} \mathrm{~N} /{ }^{14} \mathrm{~N}\right.$, expressed as $\delta^{15} \mathrm{~N}$ values in per mil notation) in consumers are expected to exhibit a ${ }^{15} \mathrm{~N}$ enrichment relative to their diets, and thereby reveal, in addition to its use as a proxy for animal's diet, its trophic position. ${ }^{21,22}$ However, linking the degree of heterotrophy to potential changes in coral $\delta^{15} \mathrm{~N}$ values is elusive. ${ }^{14}$ Coral host tissues do not typically present the expected ${ }^{15} \mathrm{~N}$ enrichment compared with their symbionts, which might be explained by the recycling of nitrogen within the symbiotic association. ${ }^{23}$ In corals, light nitrogen $\left({ }^{14} \mathrm{~N}\right)$ of waste products is transferred to the Symbiodiniaceae, therefore reducing the isotopic ratios of the Symbiodiniaceae, and also of the host, by the transfer of photosynthates. $^{23,24}$ Although, there is now a better knowledge of how corals and their algal partners cooperate to share nutrient resources, the complex aspects of metabolic interactions (i.e., flux and destination of metabolites) are still unclear. ${ }^{3}$ Further, carbon and nitrogen stable isotope experiments may further reveal the ecological (nutritional) functions of the dense, diverse microbial communities that scleractinian corals harbour in their tissues and skeletons. ${ }^{25,26}$

Sample preparation and treatment prior to the analytical determination of stable isotope ratios are of critical importance to achieve high-quality stable isotope data. However, there are marked differences among studies concerning the methods used for sample preparation in order to determine stable isotope ratios (see Table 1).
These differences in the methods used to treat samples may influence the results and introduce potential biases in food-web models, which could lead to incorrect interpretations and hamper the comparability of stable isotope data among different studies. In particular, biases may result from four different processing sources: drying, lipid extraction, acidification, and water washing.

Sample drying is required for carbon and nitrogen SIA, and different methods exist. It can be performed by freeze-drying (under a vacuum) or oven-drying at 40 to $60^{\circ} \mathrm{C}$. The first method provides total water extraction, whereas oven-drying cannot guarantee the total elimination of water. Although the oven-drying method is considered more aggressive than freeze-drying, ${ }^{33}$ studies on marine organisms that have investigated differences in $\delta^{13} \mathrm{C}$ and $\delta^{15} \mathrm{~N}$ values due to the drying method have reported variable results. ${ }^{34-36}$ In coral ecology, the effects of the different drying methods for preparing coral samples for carbon and nitrogen SIA are unknown; however, the oven-drying method could cause enrichment of ${ }^{15} \mathrm{~N}$ or ${ }^{13} \mathrm{C}$ due to the evaporation of some volatile compounds that are richer in lighter isotopes (e.g., lipids ${ }^{36}$ ). Samples are sometimes ovendried and sometimes freeze-dried without supporting evidence for the choice of method used (Table 1), which probably depends upon the availability of equipment in the laboratory.

Corals contain variable amounts of total lipid, which accounts for 9 to $47 \%$ of their dry tissue weight ${ }^{37-40}$ depending on light level, ${ }^{37}$ water temperature, ${ }^{41}$ reproductive activity, ${ }^{42}$ and nutritional

TABLE 1 Examples of variability in sample preparation methods for carbon and nitrogen stable isotope measurements of scleractinian coral tissues with respect to drying, lipid extraction, acidification, and water washing treatments prior to isotope ratio mass spectrometry. The list of studies is illustrative and is not intended to cover the whole body of literature in scleractinian coral samples

\begin{tabular}{|c|c|c|c|c|c|c|}
\hline Sources & $\begin{array}{l}\text { Stable } \\
\text { isotopes }\end{array}$ & Drying & $\begin{array}{l}\text { Lipid } \\
\text { extraction }\end{array}$ & \multicolumn{2}{|l|}{ Acidification } & $\begin{array}{l}\text { Washing } \\
\text { Animal \& } \\
\text { algae }\end{array}$ \\
\hline Alamaru et $\mathrm{al}^{13}$ & $\mathrm{CN}$ & Oven-dried & Yes $^{c}$ & No & Yes, direct & Yes \\
\hline Einbinder et $\mathrm{al}^{27}$ & $\mathrm{C}$ & Freeze-dried & No & Yes, direct & $\mathrm{Ni}$ & No \\
\hline Grottoli et $\mathrm{al}^{28}$ & $\mathrm{C}$ & $\mathrm{Ni}$ & No & No & Yes, direct & Yes \\
\hline Heikoop et al $^{29}$ & $\mathrm{~N}$ & Freeze-dried & No & Yes, direct ${ }^{\mathrm{e}}$ & & Yes \\
\hline Lesser et al ${ }^{17}$ & $\mathrm{CN}$ & $\mathrm{Ni}$ & No & No & Yes, direct & No \\
\hline Maier et $\mathrm{al}^{18}$ & $\mathrm{CN}$ & Oven-dried & No & $\mathrm{No}^{f}$ & $\mathrm{No}^{f}$ & No \\
\hline Muscatine et al ${ }^{30}$ & $\mathrm{C}$ & Oven-dried + freeze-dried ${ }^{b}$ & $\mathrm{No}^{\mathrm{d}}$ & Yes, direct ${ }^{g}$ & Yes, direct ${ }^{g}$ & No \\
\hline Nahon et al ${ }^{14}$ & $\mathrm{CN}$ & Oven-dried & No & Yes, direct & Yes, direct & Yes \\
\hline Radice et $\mathrm{al}^{15}$ & $\mathrm{CN}$ & Freeze-dried & No & Yes, direct & Yes, direct & Yes \\
\hline
\end{tabular}

C: carbon, N: nitrogen, Ni: no available information

${ }^{a}$ Coral host and algal symbiont were initially freeze-dried and then oven-dried after acidification.

${ }^{b}$ Coral host and algal symbiont were initially oven-dried and then freeze-dried after acidification.

'Lipids were extracted from host and algal symbionts with the specific aim to define the carbon source utilised for lipid synthesis.

${ }^{\mathrm{d}}$ Scientists observed a surface layer of lipid droplets present on the supernatant. The supernatant was decanted with the lipids and thoroughly mixed.

e Host and algal symbiont were not separated.

${ }^{\mathrm{f}}$ Scientists highlighted that the tissue slurry was passed through a $20 \mu \mathrm{m}$ mesh gauze to remove the carbonates.

'Tissue homogenate was passed through several layers of surgical gauze to remove fragments of skeleton. Filters containing animal tissues and algal pellets were treated with phosphoric acid and not hydrochloric acid as in all other studies. 
intake. ${ }^{38}$ Lipids are depleted in ${ }^{13} \mathrm{C}$ with respect to protein and carbohydrate fractions, ${ }^{43,44}$ and the $\delta^{13} \mathrm{C}$ values of lipids in Red Sea coral species (Stylophora pistillata and Dipsastraea favus) are lower by an average of $\sim 3.5 \%$ o than those of coral host tissues. ${ }^{13}$ Therefore, in order to reduce the differences in stable isotope composition caused by variations in lipid content, lipids are generally extracted from tissues that contain relatively large amounts of lipids. ${ }^{45}$ Lipids are commonly removed by extracting powdered samples in a 2:1 (by volume) chloroform/methanol solution ${ }^{13,46-49}$ or by using an effective and less toxic dichloromethane/methanol mixture. ${ }^{50}$ Because of the possible removal of some protein $\mathrm{N}$-containing compounds (i.e., amino acids), lipid extraction may affect $\delta^{15} \mathrm{~N}$ values. ${ }^{44,51}$ Although it depends on the research question, only a few studies have considered lipid extraction in coral SIA until now (e.g., ${ }^{13,49}$; Table 1), and there is no consensus on whether it is necessary to account for lipid removal from coral tissues or not.

The presence of inorganic carbonate structures in scleractinian corals may alter the carbon isotopic composition because they are more enriched in ${ }^{13} \mathrm{C}$ than soft tissue and thus bias the isotope signal $\left(\delta^{13} \mathrm{C}\right.$ values) of organic matter, which is of primary interest in trophic ecology. For this reason, removing inorganic carbon through acidification is a necessary step in coral sample preparation. When isolating animal tissues and Symbiodiniaceae from the skeleton, it is not always possible to remove all the carbonated fragments. Similarly, for lipid extraction, treating samples with acid can have unintended consequences for the nitrogen isotope ratios $\left(\delta^{15} \mathrm{~N}\right.$ values) that are altered during the process. ${ }^{35,52}$ This bias is variable, both in extent and in direction, and generally not predictable. ${ }^{34,53}$ The application of acid to coral material has been inconsistent among investigators (Table 1), and no consensus exists regarding whether or not to acidify the type of tissue (coral animal vs symbiont algal fractions) or what method to use (direct application vs fuming acidification). Direct acidification consists of slowly adding drops of hydrochloric acid $(\mathrm{HCl})$ to dry, powdered material in glass vials, whereas fuming acidification, which is considered less aggressive, consists of fumigating the samples with $\mathrm{HCl}$ in a closed chamber. After acidification, some researchers further wash the acidified samples with distilled water before re-drying, whereas others do not (Table 1). This procedure was initially developed to eliminate acid (and, in some cases, salts) from samples, but has provided inconsistent results in marine organisms ${ }^{35,51,54}$ and it has not yet been tested in coral samples. Therefore, in order to meaningfully compare stable isotope ratios obtained in different studies, there is an urgent need to assess potential biases associated with the various methods and develop a suitable, standardised preparation protocol for coral ecologists.

The aim of this study was to examine the effects of drying method, lipid extraction, acidification, and water washing on the carbon and nitrogen stable isotope ratios of two common, morphologically different scleractinian coral species. Based on a thorough review of the literature and the results of this study, we propose guidelines toward a standardised SIA protocol for scleractinian corals.

\section{2 | MATERIAL AND METHODS}

\section{1 | Study species}

We chose two common, reproductively and morphologically different (i.e., colony morphology, skeletal porosity, tissue thickness, and polyp size) scleractinian corals as model organisms. The branching coral Stylophora pistillata (Esper, 1797) is a hermaphrodite brooder, a fastgrowing and an important reef builder, and is commonly described as opportunistic (i.e., a typical coloniser of unpredictable environments). ${ }^{55}$ The massive coral Porites lutea (Milne Edwards, 1860 ) is a gonochoric spawner. It is also an important reef builder characterised by a long-lived life history strategy, relatively slow growth rate, and a certain ability to tolerate stress. ${ }^{56,57}$ Species were identified based on their morphological characters: $P$. lutea's corallites exhibit an obvious triplet of fused septa and five tall pali, which are characteristics of the species in massive colonies; and macro- and micro- features identified in S. pistillata, which is very distinctive at the sampling location. ${ }^{58}$

\section{2 | Coral sampling}

Seven colonies of $S$. pistillata and five colonies of $P$. lutea were sampled in April and May 2017 at a $10 \mathrm{~m}$ depth from Bitou Cape, North Taiwan $\left(25^{\circ} 07^{\prime} 34^{\prime \prime} \mathrm{N}\right.$; $\left.121^{\circ} 54^{\prime} 48^{\prime \prime} \mathrm{E}\right)$. From each of the 12 colonies, we collected between two and five fragments $\left(10 \mathrm{~cm}^{2}\right)$ using a hammer and chisel. Fragments of each colony were pooled together to obtain sufficient biological material for each sample. Immediately after collection, samples were snap-frozen in liquid nitrogen, transported to the laboratory, and frozen at $-20^{\circ} \mathrm{C}$. Field sampling was performed under Collection Permit No. 1063332556 issued by the Fisheries and Fishing Port Affairs Management Office, New Taipei City Government, Taiwan.

\section{3 | Coral preparation}

Tissues were removed from the skeletons of thawed corals with an airbrush (pressure set at maximum 4 bars) connected to a reservoir, which used approximately 30 to $50 \mathrm{~mL}$ of artificial seawater (Instant Ocean, Aquarium Systems Inc., Eastlake, OH, USA). The resulting slurry contained both animal tissues and Symbiodiniaceae, and was homogenised for 3 min using an Ultra Turrax Ika-T10 basic disperser (Ika-Werke Inc., Staufen, Germany) in order to smooth the slurry and release Symbiodiniaceae from the host tissues. The homogenate was centrifuged for $10 \mathrm{~min}$ at $2000 \mathrm{~g}$ at $4^{\circ} \mathrm{C}$ (Heraeus Megafuge 8R, Thermo Fisher Scientific, Waltham, MA, USA) in order to separate the homogenate into animal (i.e., host) and algal (i.e., Symbiodiniaceae) fractions. The supernatant containing the animal fraction was inspected under a microscope to confirm the purity of the coral host. If Symbiodiniaceae were detected, the supernatant was re-centrifuged at the same speed and time to pelletise any 
residual Symbiodiniaceae, and inspected again. The process was repeated until Symbiodiniaceae could not be detected.

The symbiodinian pellets from the first centrifugation were washed, re-suspended in $\sim 3 \mathrm{~mL}$ Milli- ${ }^{\circledR}$ water (Merck Millipore, Burlington, MA, USA), and then centrifuged for $2 \mathrm{~min}$ at $90 \mathrm{~g}$ at $4^{\circ} \mathrm{C}$. This centrifugation speed and time were sufficient to pelletise the Symbiodiniaceae and leave residual animal tissue in suspension. The 3-mL supernatants that mainly contained coral animal debris were discarded, and washing and re-centrifugation were repeated 10 to 12 times until almost no contamination by animal constituents (e.g., nematocysts) or mucus was visible under a microscope. For the animal tissue, one part of the supernatant was retrieved in a vial for freeze-drying and the other was filtered through pre-combusted Whatman glass fiber filters (Grade GF/F, $\varnothing 47 \mathrm{~mm}$, pore size $0.7 \mu \mathrm{m}$ ) at low pressure using a vacuum pump (Chemker-411, Rocker Scientific, New Taipei City, Taiwan) for oven-drying. The supernatant volume varied from 5 to $30 \mathrm{~mL}$, according to the tissue thickness and amount of mucus of each sample.

\subsection{Experimental design and treatments}

The experimental design and treatments used in the preparation of samples for the isotopic analysis of animal tissues and Symbiodiniaceae are described in Figure 1. Given the large number of treatments and the limited quantity of material extracted from the samples, we could not realistically analyse all possible interactions among the treatments. Accordingly, we tested the main effects of three different processing steps (drying and lipid extraction of both animal and algal fractions, and acidification of the algal fractions) and the combined effects of water washing after acidification of the animal fractions, commonly met in the literature (Table 1). The test for lipid extraction, acidification, and water washing was only conducted on oven-dried samples (Figure 1).

In order to test for differences between the two drying methods, the algal and animal samples were divided into two subsamples. One subsample was oven-dried at $50^{\circ} \mathrm{C}$ for at least $24 \mathrm{~h}$ (DO60 circulator oven, Deng Yng, New Taipei City, Taiwan) and the other was freezedried for about 72h (FD6-4P-D-80 freeze-dryer, Kingmech, New Taipei City, Taiwan). More specifically, the algal subsamples were oven-dried and freeze-dried directly in the vials used for centrifugation (see section 2.3), while animal subsamples were freeze-dried in vials and oven-dried on glass fiber filters. Each ovendried subsample was further divided into three groups, of which the first received lipid extraction treatment. For this treatment, the samples were soaked in a 2:1 dichloromethane/methanol solution (solvent volume about five times greater than sample volume) for $30 \mathrm{~min}$. They were then centrifuged for $10 \mathrm{~min}$ at $1400 \mathrm{~g}$, and the supernatant containing the solvent and lipids was discarded. This
(A)

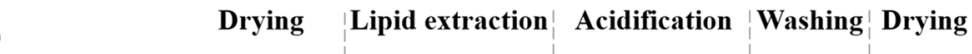

(B)

(C)

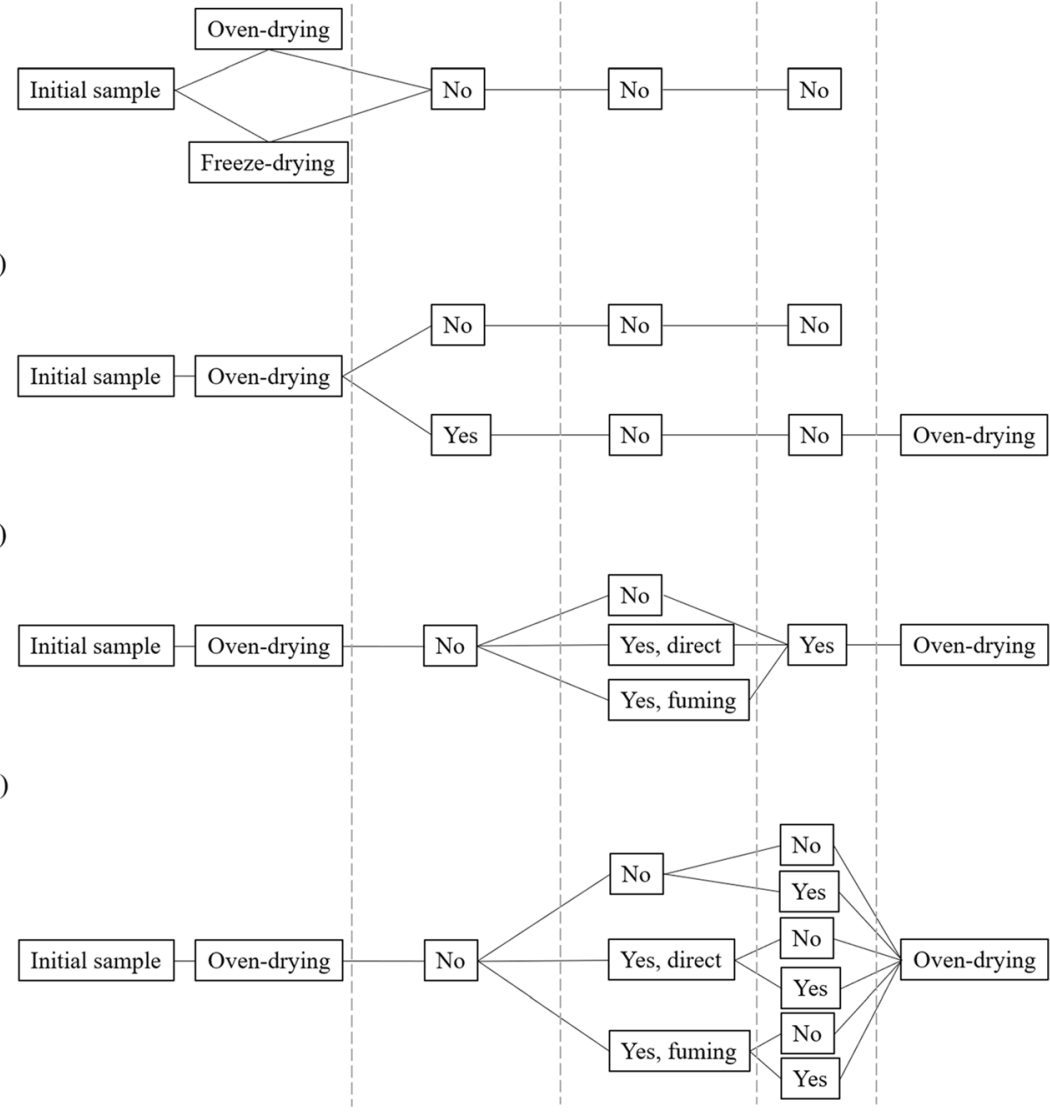

FIGURE 1 Experimental design and treatments used to prepare samples of two scleractinian coral species for stable isotope analyses. Protocols to test the effects of A, the drying method on animal tissues and Symbiodiniaceae; B, lipid extraction on animal tissues and Symbiodiniaceae; $\mathrm{C}$, acidification of Symbiodiniaceae; and D, acidification and washing using distilled water on animal tissues 
process was repeated at least three times for animal tissues and five times for Symbiodiniaceae until the supernatant was completely clear and colourless. To remove the remaining solvent, the vials containing the subsamples were oven-dried at $50^{\circ} \mathrm{C}$ for $24 \mathrm{~h}$. In the second group, the algal and animal subsamples were acidified by adding $1 \mathrm{~N} \mathrm{HCl}$ (drop-by-drop) and left in acid to remove carbonates (the cessation of bubbling was used as the criterion to determine the amount of acid to add and the time left in the acid). ${ }^{59}$ The third group, consisting of algal and animal subsamples, was fumigated with $37 \% \mathrm{HCl}$ (Honeywell Fluka ${ }^{\mathrm{TM}}$, CAS number: 7647-01-0) in a closed chamber for $24 \mathrm{~h}$. For algal fractions, the subsamples were rinsed with distilled water and centrifuged for $5 \mathrm{~min}$ at $2000 \mathrm{~g}$ at $4^{\circ} \mathrm{C}$. Then, the water was discarded and the cycle was repeated twice. For animal tissues, half of the subsamples were rinsed on the filters with small portions of distilled water to test the effects of a waterwashing treatment. The water volume was approximately equivalent to the volume of acid added drop-by-drop, and it was then discarded. Lipids were not extracted from the second and third group treatments (i.e., prior to direct and fuming acidification, respectively).

All the prepared samples were oven-dried at $50^{\circ} \mathrm{C}$ (except for the freeze-dried subsamples) and then ground into a homogeneous fine powder with a mortar and pestle (for filters, the surface layer containing portions of the glass fiber filter and the animal fraction was scraped). For each sample, around $0.7 \mathrm{mg}$ of powder of Symbiodiniaceae and around $5 \mathrm{mg}$ of powder of animal tissues and filters were weighed into tin capsules, and stored in an oven at $50^{\circ} \mathrm{C}$ until analysis.

\section{3 | SIA}

The stable isotope ratios of carbon $\left({ }^{13} \mathrm{C} /{ }^{12} \mathrm{C}\right)$ and nitrogen $\left({ }^{15} \mathrm{~N} /{ }^{14} \mathrm{~N}\right)$ in animal tissues and Symbiodiniaceae were measured at the Institute of Oceanography of the National Taiwan University using an isotope ratio mass spectrometer (DELTA $\vee$ Advantage, Thermo Fisher Scientific) coupled in continuous flow to an elemental analyser (FLASH 2000, Thermo Fisher Scientific). Stable isotope ratios are conventionally expressed as $\delta$ values in $\%{ }^{60}$ relative to Vienna Pee Dee Belemnite for carbon isotopes and atmospheric $\mathrm{N}_{2}$ for nitrogen isotopes. Certified reference material USGS40 (L-glutamic acid: $\left.\delta^{13} C=-26.4 \pm 0.1 \% ; \quad W_{C}=40.8 \% ; \quad \delta^{15} N=-4.5 \pm 0.1 \% ; \quad W_{N}=9.5 \%\right)$, obtained from the International Atomic Energy Agency (IAEA, Vienna, Austria), was inserted into all runs at regular intervals (once every eight analyses) for data calibration. To assess drift over time, repetitive measurements of an internal standard (protein: $\delta^{13} \mathrm{C}=$ $-27.3 \pm 0.1 \%$; $\delta^{15} \mathrm{~N}=6.0 \pm 0.1 \%$ o) were also used. The standard deviation for multi-batch replicate measurements of the standards analysed, interspersed among the samples, was $\leq 0.2 \%$ of both $\delta^{13} \mathrm{C}$ and $\delta^{15} \mathrm{~N}$ values. Elemental data of animal tissues and Symbiodiniaceae are expressed as a ratio between the concentrations of carbon and nitrogen ( $\mathrm{C} / \mathrm{N}$ mass ratios), measured relative to the \%dry mass.

\section{1 | Statistical analyses}

The effects of the drying and lipid-extraction treatments were tested by performing paired Student $t$-tests on the stable isotope data. The effects of acidification and washing with distilled water after acidification were tested by a repeated-measures analysis of variance (ANOVA). Data were checked for normality using ShapiroWilk's test and sphericity using Mauchly's test. If the assumption of sphericity was violated, adjusted $p$-values from Greenhouse-Geisser corrections were used. If the ANOVA revealed a significant difference, the source of the difference was identified using Tukey's Honest Significant Difference test. All the analyses were performed using Statistica 12 (StatSoft) with significance level set at 0.05 .

\section{4 | RESULTS}

The drying method did not cause any significant differences in the $\delta^{13} \mathrm{C}$ and $\delta^{15} \mathrm{~N}$ values, with the exception of $P$. lutea animal tissue, in which the oven-dried samples had $\delta^{13} \mathrm{C}$ values that were $0.4 \%$ o lower, on average, than the freeze-dried ones ( $p=0.001$; Figure 2 and Table 2).

Lipid extraction caused a significant increase in the $\delta^{13} \mathrm{C}$ values of the algal fractions of both species $(0.3 \%)(p<0.01$; Figure 3 and Table 3), while no significant effects were observed in animal tissues. The lipid-extraction effects on $\delta^{15} \mathrm{~N}$ values varied with species and
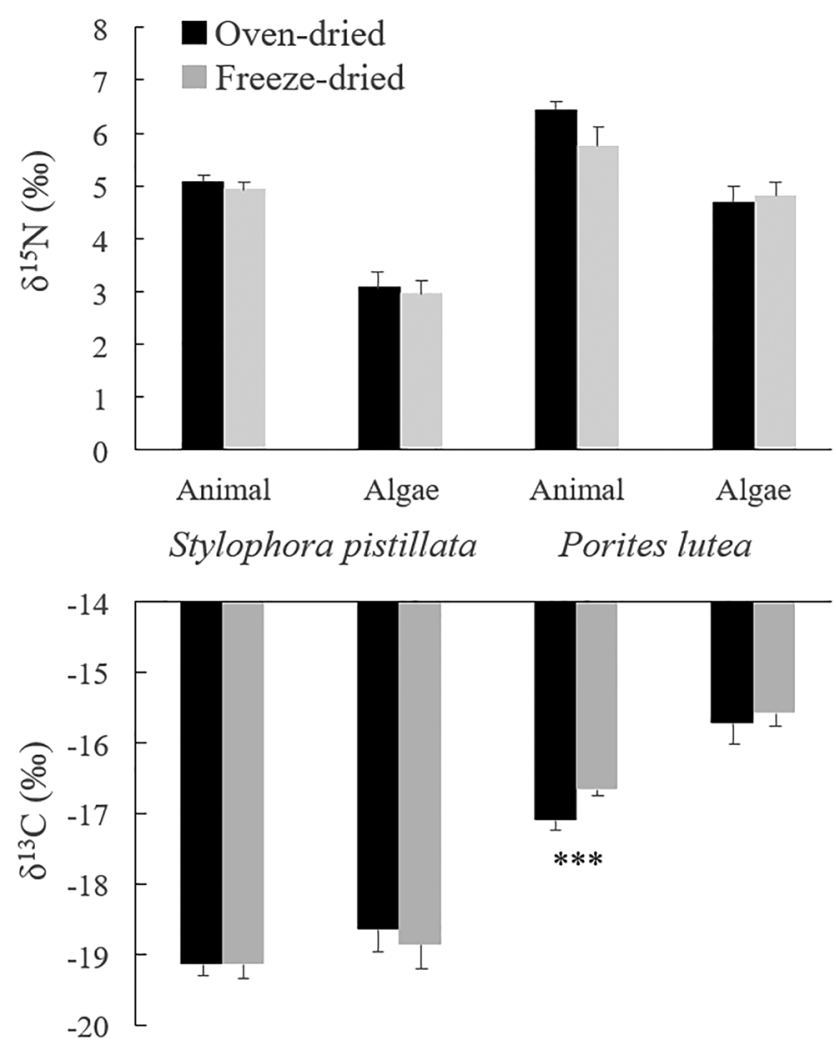

FIGURE 2 Mean ( $\pm \mathrm{SE}$ ) $\delta^{13} \mathrm{C}$ and $\delta^{15} \mathrm{~N}$ values for oven-dried and freeze-dried samples of Stylophora pistillata $(n=7)$ and Porites lutea $(n=5)$. Significant differences from paired $t$-tests are indicated ${ }^{* * *}$ $p=0.001)$ 
TABLE 2 Results of paired $t$-tests ( $t$-value and level of significance $p$ ) carried out to test the effects of drying treatments (freeze-drying vs oven-drying) in the $\delta^{13} \mathrm{C}$ and $\delta^{15} \mathrm{~N}$ values of Stylophora pistillata $(n=7)$ and Porites lutea $(n=5)$. Significant $(p \leq 0.05)$ values are in bold

\begin{tabular}{|c|c|c|c|c|c|}
\hline \multirow[b]{2}{*}{ Species } & \multirow[b]{2}{*}{ Tissue } & \multicolumn{2}{|l|}{$\delta^{13} \mathrm{C}$} & \multicolumn{2}{|l|}{$\delta^{15} \mathrm{~N}$} \\
\hline & & $t$-value & $p$ & $t$-value & $p$ \\
\hline Stylophora pistillata & $\begin{array}{l}\text { Animal } \\
\text { Algae }\end{array}$ & $\begin{array}{l}0.00 \\
-1.70\end{array}$ & $\begin{array}{l}1.000 \\
0.140\end{array}$ & $\begin{array}{l}-1.36 \\
-1.65\end{array}$ & $\begin{array}{l}0.221 \\
0.150\end{array}$ \\
\hline Porites lutea & $\begin{array}{l}\text { Animal } \\
\text { Algae }\end{array}$ & $\begin{array}{l}8.63 \\
1.06\end{array}$ & $\begin{array}{l}0.001 \\
0.347\end{array}$ & $\begin{array}{l}-1.74 \\
2.06\end{array}$ & $\begin{array}{l}0.157 \\
0.109\end{array}$ \\
\hline
\end{tabular}

tissue: the values increased in the algal fractions of $S$. pistillata $(0.2 \%)$ but not in those of $P$. lutea $(p<0.01$; Figure 3 and Table 3$)$. For the algal fractions, the mean $\mathrm{C} / \mathrm{N}$ ratios were significantly lower in lipidextracted samples for S. pistillata and P. lutea (ratios of 4.2 and 4.9, respectively) than in non-treated samples (ratios of 6.2 and 6.4, respectively; $p$ <.001). For the animal tissues, the mean $\mathrm{C} / \mathrm{N}$ ratio of S. pistillata was significantly lower in lipid-extracted samples than in non-treated samples (ratios of 4.4 and 6.3, respectively; $p<0.001$ ), and was not different for P. lutea (ratios of 5.8 and 6.3, respectively; $p=0.059$ ).

Acid treatment (direct and fuming) significantly altered the carbon isotope ratios of the algal fractions of both species, causing a shift

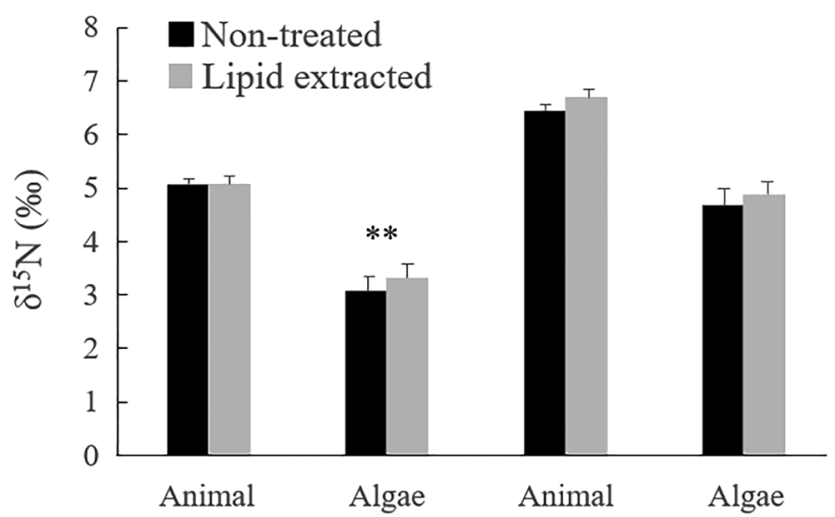

Stylophora pistillata

Porites lutea

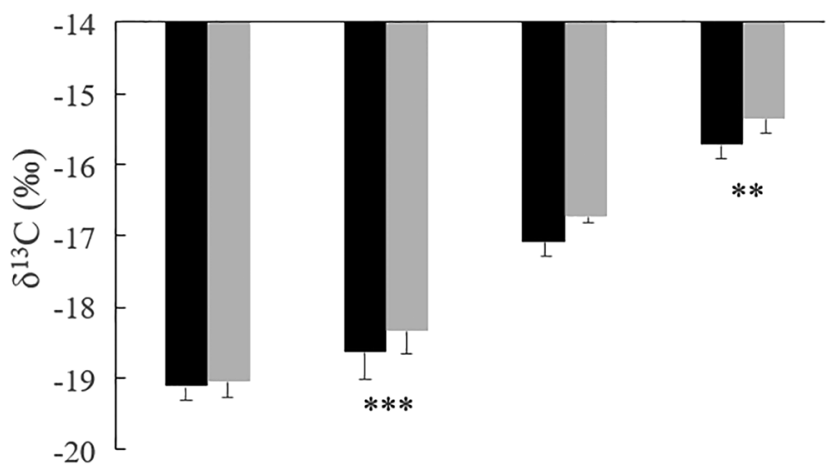

FIGURE 3 Mean $( \pm \mathrm{SE}) \delta^{13} \mathrm{C}$ and $\delta^{15} \mathrm{~N}$ values for non-treated and lipid-extracted samples of Stylophora pistillata $(n=7)$ and Porites lutea $(n=5)$. Significant differences from paired $t$-tests are indicated $(* *$ $\left.p<0.01 ;{ }^{* * *} p<0.001\right)$
TABLE 3 Results of paired $t$-tests ( $t$-value and level of significance $p$ ) carried out to test the effects of lipid extraction in the $\delta^{13} \mathrm{C}$ and $\delta^{15} \mathrm{~N}$ values of Stylophora pistillata $(n=7)$ and Porites lutea $(n=5)$. Significant $(p \leq 0.05)$ values are in bold

\begin{tabular}{|c|c|c|c|c|c|}
\hline \multirow[b]{2}{*}{ Species } & \multirow[b]{2}{*}{ Tissue } & \multicolumn{2}{|l|}{$\delta^{13} \mathrm{C}$} & \multicolumn{2}{|l|}{$\delta^{15} \mathrm{~N}$} \\
\hline & & $t$-value & $p$ & $t$-value & $p$ \\
\hline Stylophora pistillata & $\begin{array}{l}\text { Animal } \\
\text { Algae }\end{array}$ & $\begin{array}{l}1.08 \\
6.87\end{array}$ & $\begin{array}{l}0.321 \\
<0.001\end{array}$ & $\begin{array}{l}0.35 \\
4.60\end{array}$ & $\begin{array}{l}0.736 \\
0.004\end{array}$ \\
\hline Porites lutea & $\begin{array}{l}\text { Animal } \\
\text { Algae }\end{array}$ & $\begin{array}{l}2.45 \\
7.06\end{array}$ & $\begin{array}{l}0.070 \\
0.002\end{array}$ & $\begin{array}{l}2.15 \\
2.24\end{array}$ & $\begin{array}{l}0.098 \\
0.089\end{array}$ \\
\hline
\end{tabular}

towards more negative $\delta^{13} \mathrm{C}$ values $(p<0.05$; Figure 4 and Table 4) The mean \pm SE shift was $-0.5 \pm 0.1 \%$ o for direct acidification and $-0.3 \pm 0.1 \%$ o for fuming acidification, with individual samples being up to $\sim 1.1$ and $0.8 \%$ more negative, respectively. Acid treatment did not cause any significant differences in the $\delta^{15} \mathrm{~N}$ values of the algal fractions of $P$. lutea. For S. pistillata, the $\delta^{15} \mathrm{~N}$ value of the algal fraction associated with the fuming acid treatment was significantly lower than that of non-treated and direct $\mathrm{HCl}$ samples $(-0.1 \%$ on average; $p=0.01$; Figure 4 and Table 4 ), but these effects were weaker than the error associated with our analytical precision (i.e., $\leq 0.2 \%$ ).

Acid treatment (direct and fuming) caused significant differences in the $\delta^{13} \mathrm{C}$ values of the animal tissues of both species $(p<0.05$; Figure 5 and Table 5 ). The mean \pm SE shift was $-0.2 \pm 0.1 \%$ o for direct acidification and $-0.5 \pm 0.1 \%$ for fuming acidification, with individual samples being up to $\sim 0.8$ and $2.0 \%$ o more negative, respectively (Figure 5). For $P$. lutea animal tissue $\delta^{13} \mathrm{C}$ values, a significant interaction between acidification and washing $(p<0.001)$ indicated that the effect of acidification depended upon whether the samples had been washed or not. In contrast, the $\delta^{15} \mathrm{~N}$ values of $P$. lutea animal tissues were unaffected by acidification or washing. However, there was a significant interaction between acidification and washing for S. pistillata $(p=0.029)$.

\section{5 | DISCUSSION}

This study has highlighted the diversity of treatments used in the preparation of scleractinian coral tissue samples and investigated their possible effects on carbon and nitrogen isotope ratios. The main outcomes were that the (1) drying method and lipid extraction treatment had no substantial effects on algal and animal $\delta^{15} \mathrm{~N}$ or $\delta^{13} \mathrm{C}$ values in both scleractinian corals tested; (2) acid treatment caused significant differences in algal and animal $\delta^{13} \mathrm{C}$ values in both species, while no ecologically significant differences were observed in $\delta^{15} \mathrm{~N}$ values; and (3) the effects of acidification on animal $\delta^{13} \mathrm{C}$ and $\delta^{15} \mathrm{~N}$ values may depend upon water washing.

\section{1 | Effects of the drying method}

The drying method did not significantly affect the $\delta^{15} \mathrm{~N}$ values of both tissues of the two coral species. This observation is consistent with 
No acidification Direct acidification Fuming acidification

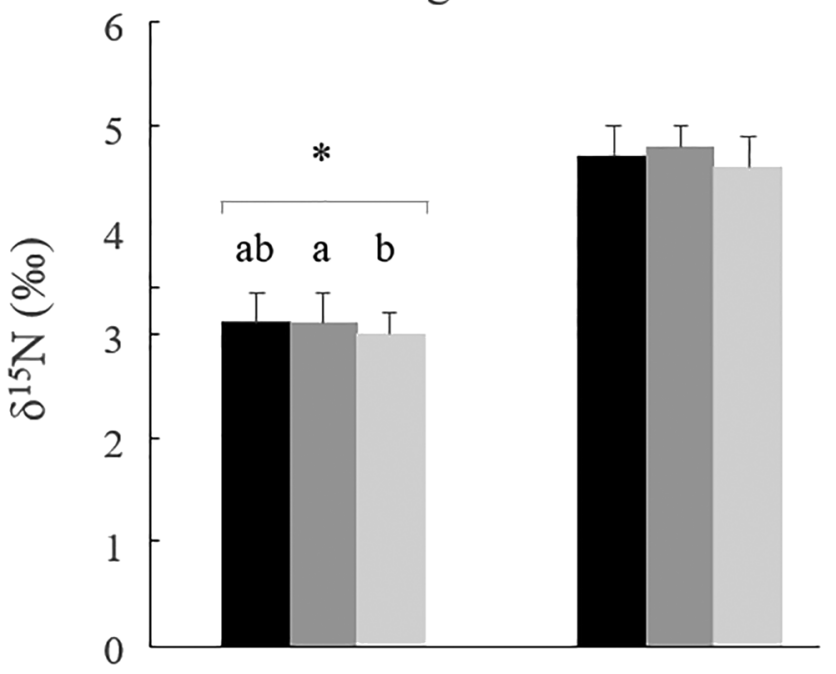

Stylophora pistillata Porites lutea

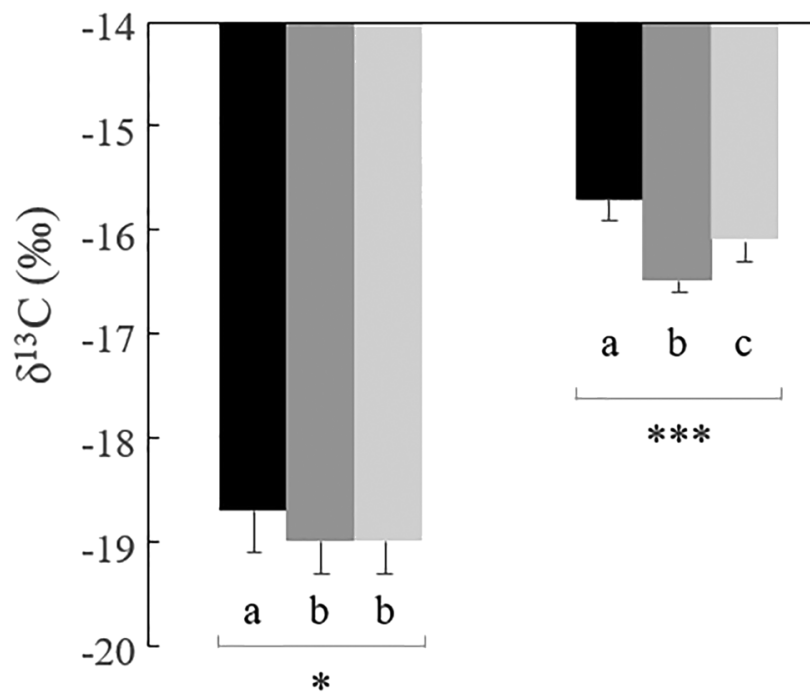

FIGURE 4 Mean $( \pm \mathrm{SE}) \delta^{13} \mathrm{C}$ and $\delta^{15} \mathrm{~N}$ values according to the different acidification treatments for Symbiodiniaceae of Stylophora pistillata $(n=7)$ and Porites lutea $(n=5)$. Significant differences from repeated measures ANOVAs are indicated $\left({ }^{*} p<0.05\right.$; $\left.{ }^{* * *} p<0.001\right)$. Bars labelled with different letters are significantly different while bars with the same letter are not significantly different from each other

results obtained in marine organisms, notably crustaceans ${ }^{34}$ and teleost fishes ${ }^{61}$ However, in other marine organisms, higher $\delta^{15} \mathrm{~N}$ values have been observed in oven-dried samples (crustaceans, a mollusc, teleost fishes, and an elasmobranch) than in their freezedried counterparts (maximum difference up to $\sim 1 \%$ o) ${ }^{36}$ while variable $\delta^{15} \mathrm{~N}$ values have been reported for filtered sedimentary organic matter and in one plankton fraction between oven-dried and freezedried samples (maximum variations of $0.8 \%$ and $0.6 \%$, respectively). ${ }^{35}$ Although the drying method may have an effect on
TABLE 4 Results of analyses of variance ( $F$ statistic and level of significance $p$ ) carried out to test the effects of acidification treatments in the $\delta^{13} \mathrm{C}$ and $\delta^{15} \mathrm{~N}$ values for Symbiodiniaceae of Stylophora pistillata $(n=7)$ and Porites lutea $(n=5)$. Significant $(p \leq 0.05)$ values are in bold

\begin{tabular}{|c|c|c|c|c|}
\hline \multirow[b]{2}{*}{ Species } & \multicolumn{2}{|l|}{$\delta^{13} \mathrm{C}$} & \multicolumn{2}{|l|}{$\delta^{15} \mathrm{~N}$} \\
\hline & $F$ & $p$ & $\bar{F}$ & $p$ \\
\hline Stylophora pistillata & 8.37 & 0.021 & 6.86 & 0.010 \\
\hline Porites lutea & 23.21 & $<0.001$ & 2.45 & 0.148 \\
\hline
\end{tabular}

certain marine organisms, it does not appear to affect the nitrogen stable isotope ratios of some coral and algal tissues.

Significant differences between the two drying treatments in carbon stable isotope ratios were observed for $P$. lutea. Oven-dried samples of animal tissue had $\delta^{13} \mathrm{C}$ values that were $0.4 \%$ o lower on average than the freeze-dried ones (i.e., oven-dried samples were more ${ }^{13} \mathrm{C}$-enriched), possibly because of the removal of volatile, isotopically lighter compounds from tissues during oven-drying (e.g., lipids contain high amount of light carbon isotopes $\left.{ }^{12} \mathrm{C}\right) .{ }^{36}$ Although the former researchers also reported a small ${ }^{13} \mathrm{C}$ enrichment in the oven-dried samples of an elasmobranch, the great majority of studies have not reported any effects in a wide range of invertebrates and fishes. ${ }^{34,35,61,62}$ Overall, the difference in $\delta^{13} \mathrm{C}$ values between the two treatments in our study was small, but could reduce the accuracy of models and trophic calculations.

Freeze-drying is a common method of removing water from biological samples. ${ }^{35,36,61}$ Although it is expensive to purchase and maintain, the equipment is easy to use and has some advantages over oven-drying. Samples can be used in other types of analyses (e.g., biochemical analysis), and the equipment allows carbon and nitrogen content to be obtained since the mass of the organic matter from the supernatant can be accurately weighed (which is not the case when using GF/F filters). The obtention of carbon and nitrogen content is useful as it is required for calculating molar $\mathrm{C} / \mathrm{N}$ ratios. Oven-drying is simple, fast, and low cost, and is probably more convenient for large sample batches. However, the additional preparatory steps for ovendrying (i.e., filtering the supernatant on pre-combusted glass fiber filters for the animal fraction, followed by scraping animal tissue off the surface of the filter) are time consuming and can be avoided if using the freeze-drying method. In addition, most coral host cells are broken during the coral preparation step and their content is dispersed in the solution. Therefore, the GF/F filters ( $0.7 \mu \mathrm{m}$ pore size) may not retain all the initial matter as some fine compounds may be lost. Although unlikely, the scraping of the surface layer of the filters to obtain material of the animal fraction may select for certain sized particulates, which may affect the analysis output of the host tissues. Eventually, glass fiber filters are more difficult to combust than organic tissue samples. This may possibly affect the analytical process and/or some items (e.g., combustion column) of the elemental analyser, and would make stable isotope analysis more costly.

Although some authors suggest that the use of freeze-drying over oven-drying is preferable for marine biological samples, ${ }^{35,36}$ our results 


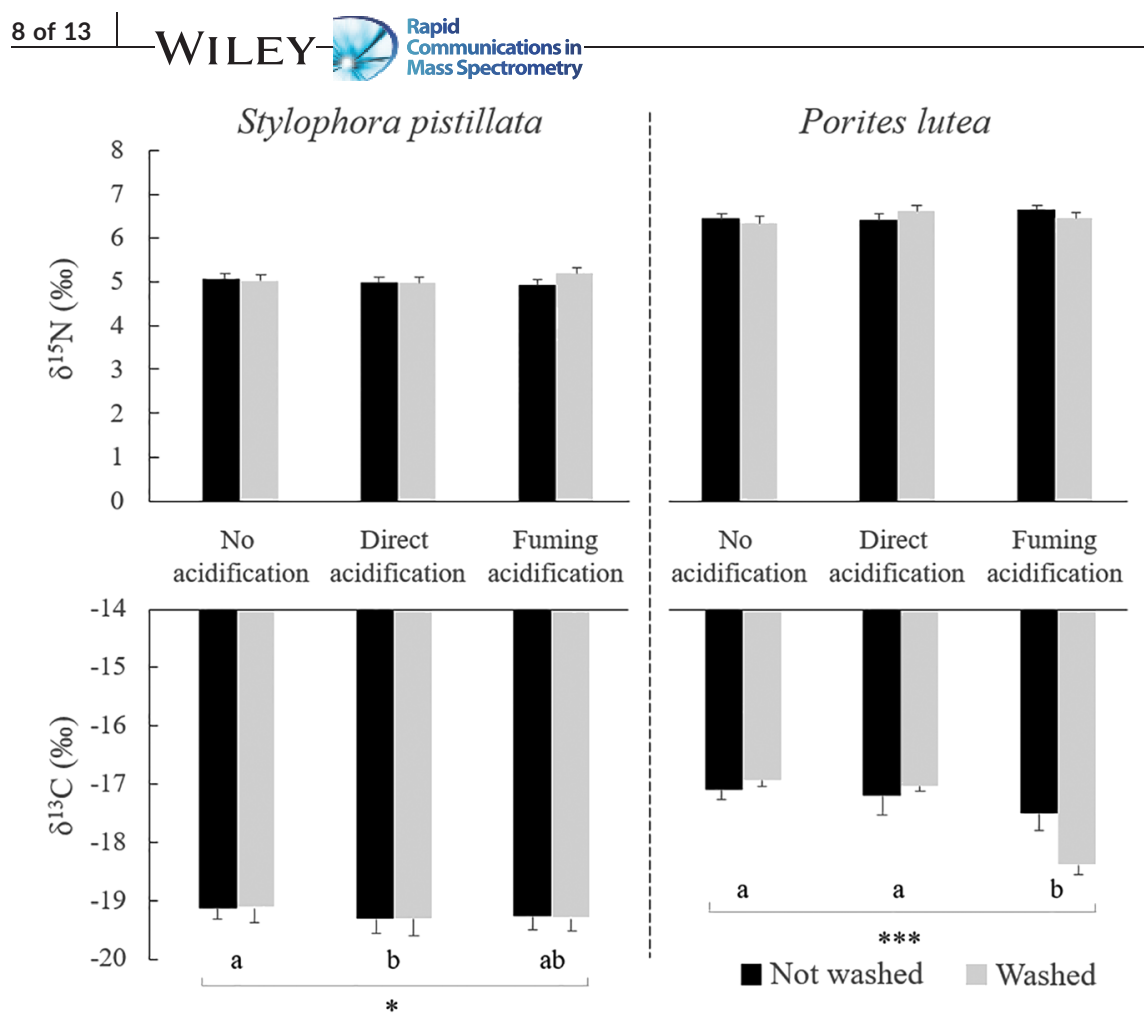

FIGURE 5 Mean $( \pm \mathrm{SE}) \delta^{13} \mathrm{C}$ and $\delta^{15} \mathrm{~N}$ values according to the different acidification and washing treatments for animal tissues of Stylophora pistillata $(n=7)$ and Porites lutea $(n=5)$. Significant differences from repeated measures ANOVAs are indicated ${ }^{*} p<0.05$; *** $p<0.001$ ). The pair of bars labelled with different letters are significantly different while the pair of bars with the same letter are not significantly different from each other

indicate that the two methods are equally acceptable for preparing coral samples for bulk carbon and nitrogen SIA, with each having its own advantages and disadvantages.

\section{2 | Effects of lipid extraction}

Although not a routine treatment, particularly for corals (see Table 1), lipids are occasionally extracted from biological samples for carbon SIA. ${ }^{51}$ As lipids are ${ }^{13} \mathrm{C}$-depleted compared with proteins and carbohydrates, ${ }^{43-45}$ lipid extraction reduces the variability attributed to differences in lipid content across tissue samples. ${ }^{20,45}$ Moreover, the lipid fractions of both coral animal tissues and Symbiodiniaceae of S. pistillata are significantly depleted in ${ }^{13} \mathrm{C}$ compared with bulk organic materials. ${ }^{13}$ Therefore, lipid extraction should result in ${ }^{13} \mathrm{C}$ enriched samples, which is consistent with our results for Symbiodiniaceae.

In our study, the lipid extraction of algal fractions caused a significant increase in the $\delta^{13} \mathrm{C}$ values of both species (0.3\%), but no significant effects were observed for animal tissues. As the $\mathrm{C} / \mathrm{N}$ ratios of animal tissues and Symbiodiniaceae were similar (between
6.2 and 6.4), this result may not be linked to differences in lipid content between the two tissues. Indeed, the $\mathrm{C} / \mathrm{N}$ ratio is considered a good proxy of lipid content. ${ }^{63}$ In addition, an association between the $\mathrm{C} / \mathrm{N}$ ratio and the percentage of lipids (dry tissue weight) has been reported in a range of marine animals. ${ }^{64}$ This increase was slightly larger than the error associated with analytical variability $(\leq 0.2 \%$ ), so it would have little influence on the interpretation of food webs, especially when investigating scleractinian corals where carbon stable isotope ratios often spatially and temporally differ to a greater degree. ${ }^{14,30}$

Lipid extraction caused a small $\delta^{15} \mathrm{~N}$ alteration in the algal fractions of $S$. pistillata, but not in $P$. lutea. This small increase $(\sim 0.2 \%$ o) may be attributed to the removal of amino acids from the tissue. Methanol is a polar solvent that is particularly effective in extracting structural lipids (e.g., glycolipids and phospholipids) that are attached to proteins. ${ }^{51,63,65}$ Therefore, methanol could leach out amino acids when the structural lipids are removed, contributing to ${ }^{15} \mathrm{~N}$ enrichment of the tissue. ${ }^{44}$ Although some studies have shown that the effects of lipid extraction on $\delta^{15} \mathrm{~N}$ values are among the clearest and largest, ${ }^{51}$ the small fractionation found here is similar to

TABLE 5 Results of analyses of variance ( $F$ statistic and level of significance $p$ ) carried out to test the effects of different acidification (direct and fuming acidification vs no acidification) and washing treatments (washing vs no washing) in the $\delta^{13} \mathrm{C}$ and $\delta^{15} \mathrm{~N}$ values for host tissues of Stylophora pistillata $(n=7)$ and Porites lutea $(n=5)$. Significant $(p \leq 0.05)$ values are in bold

\begin{tabular}{|c|c|c|c|c|c|c|c|c|c|c|c|c|}
\hline \multirow[b]{3}{*}{ Species } & \multicolumn{6}{|l|}{$\delta^{13} \mathrm{C}$} & \multicolumn{6}{|l|}{$\delta^{15} \mathrm{~N}$} \\
\hline & \multicolumn{2}{|c|}{ Acidification } & \multicolumn{2}{|c|}{ Washing } & \multicolumn{2}{|c|}{ Interaction } & \multicolumn{2}{|c|}{ Acidification } & \multicolumn{2}{|c|}{ Washing } & \multicolumn{2}{|c|}{ Interaction } \\
\hline & $F$ & $p$ & $F$ & $p$ & $F$ & $p$ & $F$ & $p$ & $F$ & $p$ & $F$ & $p$ \\
\hline Porites lutea & 23.23 & $<0.001$ & 0.63 & 0.473 & 21.38 & $<0.001$ & 0.85 & 0.464 & 0.05 & 0.839 & 0.78 & 0.489 \\
\hline
\end{tabular}


that found by previous researchers ${ }^{44,64-66}$ and is not much more than the typical analytical error for $\delta^{15} \mathrm{~N}$ analyses using continuous flow techniques ( 0.1 to $0.3 \%$ o depending on the study).

Overall, our results suggest that lipid extraction may not be needed for coral samples prior to SIA. However, it should be noted that the reproductive status of coral species may influence tissue lipid content. ${ }^{40,67}$ Our samples were collected in April and May in North Taiwan. In this area, spawning is usually observed in July for Porites spp., and previous studies have not reported any S. pistillata colonies brooding. ${ }^{68}$ In addition, different species of corals may contain variable amounts of lipid depending also on other factors such as light level, water temperature, and nutritional intake. ${ }^{37-40}$ In some particular cases, we expect that lipid extraction may become more important for coral samples, so caution must be exercised in interpreting the effects of lipid extraction on isotopic ratios and samples with different lipid contents should be tested, which is beyond the aim of the present study.

\subsection{Effects of acidification}

Calcium carbonate fragments are usually found in the coral homogenate after airbrushing the tissue from the skeleton, so they can affect the isotope ratios of soft organic tissues. Such samples are generally acidified (but not always, see Table 1) during laboratory processing to remove inorganic carbon that may introduce a bias in the carbon stable isotope ratios, as carbonates are enriched in ${ }^{13} \mathrm{C}$ with respect to soft tissues. An essential assumption of this acidification step is that it removes inorganic carbon but does not remove the carbon and nitrogen that are associated with the organic fraction.

The general effect of acid treatment was a shift towards more negative $\delta^{13} \mathrm{C}$ values in the two species and tissues examined. This output is consistent with the desired objective of removing carbonates, the non-dietary fraction of the samples. It is also the most frequent outcome of studies that have investigated the effects of acidification on marine invertebrates (average up to $0.9 \%$ o decrease). ${ }^{35,51}$ Our results are in agreement with those of other researchers, who reported that acidification decreases the $\delta^{13} \mathrm{C}$ values of scleractinian samples that contain carbonates. ${ }^{14}$ Although most carbonate fragments may have aggregated with symbiodinian pellets during centrifugation, the magnitude of the effect was in the same average range of values $(-0.2$ to $-0.5 \%$ ) for animal tissues and Symbiodiniaceae using direct or fuming acidification. Surprisingly, the greatest effect of acid treatment was on the animal tissue of $P$. lutea using fuming acidification, which is usually considered less aggressive than direct acidification. For water-washed and fuming-acidified samples, the $\delta^{13} \mathrm{C}$ values of the individual samples were up to $\sim 0.8$ to $2.0 \%$ more negative than those of the non-acidified samples. If animal tissues have a lower carbonate content than algal samples, acidification may also have removed significant amounts of heavy carbon fractions from the organic matter due to the disintegration of cells and tissues and the possible break-up of complex compounds that are subsequently lost by washing with water. ${ }^{51}$
The effects of acidification on $\delta^{15} \mathrm{~N}$ values are less consistent across studies than those on $\delta^{13} \mathrm{C}$ values. ${ }^{35,51}$ In some cases, $\delta^{15} \mathrm{~N}$ values have increased (e.g., penaeid shrimps ${ }^{52}$ ), decreased (e.g., crustaceans ${ }^{35}$ ), or experienced no modifications (e.g., penaeid shrimps and fish $^{34}$ ). As calcium carbonates do not contain nitrogen, it is assumed that any nitrogen removed originates in organic matter and so is an unwanted effect. For this reason, the nitrogen stable isotope ratios of acid-treated samples are usually measured separately from those of non-treated samples in marine invertebrates. ${ }^{52,69}$ However, this is not always the case, ${ }^{70}$ particularly in scleractinian corals, in which most studies have measured the carbon and nitrogen isotope compositions in the same acidified samples. ${ }^{11,13,14,17,19,49}$ Some studies have shown that rapidly rinsing samples with weak concentrations of $\mathrm{HCl}(1 \mathrm{~N})$ does not significantly affect nitrogen isotope ratios, as the shift between acidified and untreated samples was within the error margin of the isotope ratio mass spectrometer. ${ }^{14,29}$ Similarly, we did not observe any substantial differences in $\delta^{15} \mathrm{~N}$ values between acidified and untreated samples.

Washing samples with distilled water after acidification is commonly used in macrobenthic organisms and corals to remove acid or remaining salts ${ }^{70,71}$ (Table 1). Our results indicate that there is little justification for washing acidified samples of coral animal tissue with water. The significant interactions observed between acidification and washing for $P$. lutea and $S$. pistillata indicate that the effects of acidification on $\delta^{13} \mathrm{C}$ and $\delta^{15} \mathrm{~N}$ values depend upon the washing treatment, which makes interpretation more difficult. Therefore, as examined in other marine organisms ${ }^{35,59}$ and recommended by the majority of researchers, we do not recommend washing samples of coral animal tissue with distilled water after $\mathrm{HCl}$ application. However, possible disadvantages to not washing with water include the possibility of shortening the mean lifespan of the combustion column in the elemental analyser because of the increased content of halogen compounds (i.e., chloride from $\mathrm{HCl}$ ), ${ }^{51}$ and the remaining acid may attack the tin capsules in which samples are encapsulated, with associated sample loss. Nesting two tin capsules per sample, using silver capsules, or running the samples immediately after encapsulation (as in the present study) may overcome this issue but may increase analysis cost in the case of using silver capsules.

Acid treatment is required for the carbon SIA of animal tissues and Symbiodiniaceae in scleractinian coral samples. Acidified samples can also be used for nitrogen isotope analysis, as no substantial effects of acid treatment were observed on $\delta^{15} \mathrm{~N}$ values. This is important, because it is often difficult to obtain a reasonable amount of symbiodinian organic matter from small coral fragments and would make analyses less costly and time consuming.

\section{4 | Recommendations for standardisation}

In light of our findings, we make the following recommendations for standardising sample preparation for carbon and nitrogen stable isotope measurements in scleractinian coral tissues (see also Appendix S1, supporting information): 
1. As there were no, or only small, differences between the drying methods, both are equally acceptable for preparing coral samples for carbon and nitrogen SIA. We suggest choosing the method based on its availability and adequacy with regard to the study objectives. Freeze-drying obtains the carbon and nitrogen composition percentages of animal tissues because there is no need to use filters, and the samples can be used in other biochemical analyses.

2. Lipid extraction may not be needed prior to SIA in light of the two species analysed. As chemical lipid extraction methods are time consuming (i.e., see protocol in section 2.4), this is an advantage. However, the high variability in lipid content among coral species related to different factors (e.g., reproductive period ${ }^{40,67}$ ) leads us to recommend that researchers should examine the need for lipid extraction on a case-by-case basis.

3. The acid treatment of coral animal tissues and Symbiodiniaceae prior to SIA is essential to obtain unbiased information about trophic relationships and the origin of organic matter sources. As a standard procedure, we recommend acidifying samples with $1 \mathrm{~N} \mathrm{HCl}$ (direct acidification) and not washing animal tissue samples with distilled water. As little $\mathrm{HCl}$ as possible should be used via the drop-by-drop technique, ${ }^{59}$ and the cessation of bubbling should be used as the criterion for determining the total amount of $\mathrm{HCl}$. Whenever possible, it is advisable to gently airbrush samples (with a fixed pressure of maximum 4 bars) and avoid the waterpik method, which may be too aggressive and scrapes off more carbonate fragments. We also recommend that hard visible fragments should be removed prior to the acid treatment so that carbonate elimination is easier, and in some cases the variability of results may decrease. ${ }^{35}$ Stable isotopes of carbon and nitrogen can then be measured on the same acidified material.

Our results highlight the importance of testing for the effects of sample preparation methods on carbon and nitrogen stable isotopes in scleractinian corals. Although, this study targets two scleractinian corals characterised by different morphological and ecological properties (i.e., reproduction, colony morphology, skeletal porosity, tissue thickness, and polyp size), we do not exclude that the recommended protocol (Appendix S1, supporting information) may need to be adjusted for particular cases depending on the specific properties of an individual coral species (e.g., high lipid content). Our results suggest that assessing potential biases associated with the various methods optimises sample material collection (i.e., size of the coral fragment) and saves coral researchers time and money by avoiding unnecessary sample treatments. Further progress is still needed, since even the procedure selected for the same treatment may significantly affect isotopic ratios (e.g., the type of acid or acid concentration used, the solvent used for lipid extraction, and the application of acid to the separated algal symbiont pellet). ${ }^{52,54}$ Efforts should continue in this direction in order to understand the chemical processes that occur during sample preparation and reduce concerns about data quality. Our data also indicate that determining trophic links should be undertaken with caution, and attempting to interpret small isotopic differences should be avoided.

\section{ACKNOWLEDGEMENTS}

The authors would like to thank all members and collaborators of the Functional Reef Ecology Lab (Institute of Oceanography, National Taiwan University, Taiwan) for technical assistance during field work. They are also grateful to Ling-Wen Liu (Institute of Oceanography, National Taiwan University, Taiwan) for the stable isotope analysis. They would also like to thank anonymous referees for their critical comments and suggestions which greatly improved the manuscript. This work was funded by the Ministry of Science and Technology (MOST, Taiwan) through grants to VD (Nos. 104-2611-M-002-020MY2, 106-2611-M-002-008 and 107-2611-M-002-011) and to PLW (No. 107-2119-M-002-032). It also received financial support from the Ministry of Education (MOE, Taiwan, No. 108L901002). NS was a recipient of a National Taiwan University (NTU, Taiwan) postdoctoral fellowship ( 106R4000).

\section{Data Availability Statement}

Isotope data are freely available in the Dryad Digital Repository: https://doi.org/10.5061/dryad.xsj3tx99s.

\section{ORCID}

Nicolas Sturaro (iD https://orcid.org/0000-0002-7225-0880

Yunli Eric Hsieh (1) https://orcid.org/0000-0002-8745-8342

Qi Chen (1) https://orcid.org/0000-0002-7575-550X

Pei-Ling Wang (D) https://orcid.org/0000-0002-4392-3935

Vianney Denis (D) https://orcid.org/0000-0002-0914-5586

\section{REFERENCES}

1. Peterson BJ, Fry B. Stable isotopes in ecosystem studies. Ann Rev Ecolog Syst. 1987;18(1):293-320. https://doi.org/10.1146/annurev. es.18.110187.001453

2. Lepoint G, Dauby P, Gobert S. Applications of $\mathrm{C}$ and $\mathrm{N}$ stable isotopes to ecological and environmental studies in seagrass ecosystems. Mar Pollut Bull. 2004;49(11-12):887-891. https://doi.org/10.1016/j. marpolbul.2004.07.005

3. Tremblay P, Maguer JF, Grover R, Ferrier-Pagès C. Trophic dynamics of scleractinian corals: stable isotope evidence. J Exp Biol. 2015;218:1223-1234. https://doi.org/10.1242/jeb.115303

4. Weber JN, Woodhead PMJ. Carbon and oxygen isotope fractionation in the skeletal carbonate of reef-building corals. Chem Geol. 1970;6:93-117. https://doi.org/10.1016/0009-2541(70)90009-4

5. Swart PK, Leder JJ, Szmant AM, Dodge RE. The origin of variations in the isotopic record of scleractinian corals: II. Carbon. Geochim Cosmochim Acta. 1996;60(15):2871-2885. https://doi.org/10.1016/ 0016-7037(96)00119-6

6. Muscatine L, Goiran C, Land L, Jaubert J, Cuif JP, Allemand D. Stable isotopes $\left(\delta^{13} \mathrm{C}\right.$ and $\left.\delta^{15} \mathrm{~N}\right)$ of organic matrix from coral skeleton. Proc Natl Acad Sci U S A. 2005;102(5):1525-1530. https://doi.org/ 10.1073/pnas.0408921102 
7. Mizrachi I, Loya Y, Rosenfeld M, Kramarski-Winter E, Yam R, Shemesh A. The build-up of the isotopic signal in skeletons of the stony coral Porites lutea. Geochim Cosmochim Acta. 2010;74(24):7021-7030. https://doi.org/10.1016/j.gca.2010.09.012

8. Wang XT, Sigman DM, Cohen ALet al. Isotopic composition of skeleton-bound organic nitrogen in reef-building symbiotic corals: A new method and proxy evaluation at Bermuda. Geochim Cosmochim Acta. 2015;148:179-190. https://doi.org/10.1016/j. gca.2014.09.017

9. Duprey N, Wang XT, Thompson PDet al. Life and death of a sewage treatment plant recorded in a coral skeleton $\delta^{15} \mathrm{~N}$ record. Mar Pollut Bull 2017;120(1-2):109-116. https://doi.org/10.1016/j. marpolbul.2017.04.023

10. Land LS, Lang JC, Smith BN. Preliminary observations on the carbon isotopic composition of some reef coral tissues and symbiotic zooxanthellae. Limnol Oceanogr. 1975;20(2):283-287. https://doi.org/ 10.4319/lo.1975.20.2.0283

11. Yamamuro M, Minagawa M, Kayanne H. Preliminary observation on food webs in Shiraho coral reef as determined from carbon and nitrogen stable isotopes. Proc 7th Intl Coral Reef Symp. 1992;1:358-361.

12. Heikoop JM, Dunn JJ, Risk MJ, et al. $\delta^{15} \mathrm{~N}$ and $\delta^{13} \mathrm{C}$ of coral tissue show significant inter-reef variation. Coral Reefs. 2000;19(2):189-193. https://doi.org/10.1007/s003380000092

13. Alamaru A, Loya Y, Brokovich E, Yam R, Shemesh A. Carbon and nitrogen utilization in two species of Red Sea corals along a depth gradient: Insights from stable isotope analysis of total organic material and lipids. Geochim Cosmochim Acta. 2009;73(18):5333-5342. https://doi.org/10.1016/j. gca.2009.06.018

14. Nahon S, Richoux NB, Kolasinski J, et al. Spatial and temporal variations in stable carbon $\left(\delta^{13} \mathrm{C}\right)$ and nitrogen $\left(\delta^{15} \mathrm{~N}\right)$ isotopic composition of symbiotic scleractinian corals. PLoS ONE. 2013;8(12):e81247. https://doi.org/10.1371/journal. pone. 0081247

15. Radice VZ, Hoegh-Guldberg O, Fry B, Fox MD, Dove SG. Upwelling as the major source of nitrogen for shallow and deep reef-building corals across an oceanic atoll system. Funct Ecol. 2019;33(6):1120-1134. https://doi.org/10.1111/1365-2435.13314

16. Fox MD, Williams GJ, Johnson MD, et al. Gradients in primary production predict trophic strategies of mixotrophic corals across spatial scales. Curr Biol. 2018;28(21):3355-3363. https://doi.org/ 10.1016/J.CUB.2018.08.057

17. Lesser MP, Slattery M, Stat M, Ojimi M, Gates RD, Grottoli A. Photoacclimatization by the coral Montastraea cavernosa in the mesophotic zone: light, food, and genetics. Ecology. 2010;91(4):990-1003. https://doi.org/10.1890/09-0313.1

18. Maier C, Weinbauer MG, Pätzold J. Stable isotopes reveal limitations in $\mathrm{C}$ and $\mathrm{N}$ assimilation in the Caribbean reef corals Madracis auretenra, M. carmabi and M. formosa. Mar Ecol Prog Ser. 2010;412:103-112. https://doi.org/10.3354/meps08674

19. Leal MC, Ferrier-Pagès $C$, Calado R, Brandes JA, Frischer ME, Nejstgaard JC. Trophic ecology of the facultative symbiotic coral Oculina arbuscula. Mar Ecol Prog Ser. 2014;504:171-179. https://doi. org/10.3354/meps10750

20. DeNiro M, Epstein S. Influence of diet on the distribution of carbon isotopes in animals. Geochim Cosmochim Acta. 1978;42(5):495-506. https://doi.org/10.1016/0016-7037(78)90199-0

21. DeNiro M, Epstein S. Influence of diet on the distribution of nitrogen isotopes in animals. Geochim Cosmochim Acta. 1981;45(3):341-351. https://doi.org/10.1016/0016-7037(81)90244-1
22. Post DM. Using stable isotopes to estimate trophic position: models, methods, and assumptions. Ecology. 2002;83:703-718. https://doi. org/10.2307/3071875

23. Reynaud $S$, Martinez $P$, Houlbrèque F, Billy I, Allemand $D$, Ferrier-Pagès C. Effect of light and feeding on the nitrogen isotopic composition of a zooxanthellate coral: role of nitrogen recycling. Mar Ecol Prog Ser. 2009;392:103-110. https://doi.org/10.3354/meps08195

24. Muscatine L, D'Elia CF. The uptake, retention and release of ammonium by reef corals. Limnol Oceanogr. 1978;23:725-734. https://doi.org/10.4319/lo.1978.23.4.0725

25. Rosenberg E, Koren O, Reshef L, Efrony R, Zilber-Rosenberg I. The role of microorganisms in coral health, disease and evolution. Nat Rev Microbiol. 2007;5:355-362. https://doi.org/10.1038/ nrmicro1635

26. Ferrier-Pagès C, Leal MC. Stable isotopes as tracers of trophic interactions in marine mutualistic symbioses. Ecol Evol. 2019;9(1):723-740. https://doi.org/10.1002/ece3.4712

27. Einbinder S, Mass T, Brokovich E, Dubinsky Z, Erez J, Tchernov D. Changes in morphology and diet of the coral Stylophora pistillata along a depth gradient. Mar Ecol Prog Ser. 2009;381:167-174. https://doi.org/10.3354/meps07908

28. Grottoli AG, Rodrigues LJ, Juarez C. Lipids and stable carbon isotopes in two species of Hawaiian corals, Porites compressa and Montipora verrucosa, following a bleaching event. Mar Biol. 2004;145:621-631. https://doi.org/10.1007/s00227-004-1337-3

29. Heikoop JM, Dunn JJ, Risk MJ, Sandeman IM, Schwarcz HP, Waltho N. Relationship between light and the $\delta^{15} \mathrm{~N}$ of coral tissue: examples from Jamaica and Zanzibar. Limnol Oceanogr. 1998;43(5):909-920. https:// doi.org/10.4319/lo.1998.43.5.0909

30. Muscatine L, Porter JW, Kaplan IR. Resource partitioning by reef corals as determined from stable isotope composition. I. $\delta^{13} \mathrm{C}$ of zooxanthellae and animal tissue vs depth. Mar Biol. 1989;100:185-193. https://doi.org/10.1007/BF00391957

31. Swart PK, Saied A, Lamb K. Temporal and spatial variation in the $\delta^{15} \mathrm{~N}$ and $\delta^{13} \mathrm{C}$ of coral tissue and zooxanthellae in Montastraea faveolata collected from the Florida reef tract. Limnol Oceanogr. 2005;50(4):1049-1058. https://doi.org/10.4319/lo.2005.50.4.1049

32. Swart PK, Szmant A, Porter JW, Dodge RE, Tougas JI, Southam JR. The isotopic composition of respired carbon dioxide in scleractinian corals: implications for cycling of organic carbon in corals. Geochim Cosmochim Acta. 2005;69(6):1495-1509. https://doi.org/10.1016/j. gca.2004.09.004

33. de Torres C, Díaz-Maroto MC, Hermosín-Gutiérrez I, Pérez-Coello MS. Effect of freeze-drying and oven-drying on volatiles and phenolics composition of grape skin. Anal Chim Acta. 2010;660(1-2):177-182. https://doi.org/10.1016/j.aca.2009.10.005

34. Bosley KL, Wainright SC. Effects of preservatives and acidification on the stable isotope ratios $\left({ }^{15} \mathrm{~N}:{ }^{14} \mathrm{~N},{ }^{13} \mathrm{C}:{ }^{12} \mathrm{C}\right)$ of two species of marine animals. Can J Zool. 1999;56:2181-2185. https://doi.org/10.1139/ f99-153

35. Carabel S, Godinez-Dominguez E, Verisimo P, Fernandez L, Freire J. An assessment of sample processing methods for stable isotope analyses of marine food webs. J Exp Mar Biol Ecol. 2006;336:254-261. https:// doi.org/10.1016/j.jembe.2006.06.001

36. de Lecea AM, Smit AJ, Fennessy ST. The effects of freeze/thaw periods and drying methods on isotopic and elemental carbon and nitrogen in marine organisms, raising questions on sample preparation. Rapid Commun Mass Spectrom. 2011;25(23):3640-3649. https://doi.org/10.1002/rcm.5265

37. Stimson JS. Location, quantity and rate of change in quantity of lipids in tissue of Hawaiian hermatypic corals. Bull Mar Sci. 1987;41(3):889-904. 
38. Harland AD, Spencer Davies P, Fixter LM. Lipid content of some Caribbean corals in relation to depth and light. Mar Biol. 1992;113:357-361. https://doi.org/10.1007/BF00349159

39. Harland AD, Navarro JC, Spencer Davies P, Fixter LM. Lipids of some Caribbean and Red Sea corals: total lipid, wax esters, triglycerides and fatty acids. Mar Biol. 1993;117:113-117. https://doi.org/ 10.1007/BF00346432

40. Yamashiro H, Oku H, Higa H, Chinen I, Sakai K. Composition of lipids, fatty acids and sterols in Okinawan corals. Comp Biochem Physiol Part B: Biochem Mol Biol. 1999;122(4):397-407. https://doi.org/10.1016/ S0305-0491(99)00014-0

41. Yamashiro $\mathrm{H}$, Oku H, Onaga K. Effect of bleaching on lipid content and composition of Okinawan corals. Fish Sci. 2005;71(2):448-453. https:// doi.org/10.1111/j.1444-2906.2005.00983.x

42. Ward S. Two patterns of energy allocation for growth, reproduction and lipid storage in the scleractinian coral Pocillopora damicornis. Coral Reefs. 1995;14:87-90. https://doi.org/10.1007/BF00303428

43. DeNiro MJ, Epstein S. Mechanism of carbon isotope fractionation associated with lipid synthesis. Science. 1977;197(4300):261-263. https://doi.org/10.1126/science.327543

44. Sotiropoulos MA, Tonn WM, Wassenaar LI. Effects of lipid extraction on stable carbon and nitrogen isotope analyses of fish tissues: potential consequences for food web studies. Ecol Freshwater Fish. 2004;13(3):155-160. https://doi.org/10.1111/j.1600-0633.2004. 00056.x

45. Hobson KA, Welch HE. Determination of trophic relationships within a high Arctic marine food web using $\delta^{13} \mathrm{C}$ and $\delta^{15} \mathrm{~N}$ analysis. Mar Ecol Prog Ser. 1992;84:9-18. https://doi.org/10.3354/meps084009

46. Folch J, Lees M, Sloane Stanley GH. A simple method for the isolation and purification of total lipids from animal tissues. J Biol Chem. 1957;226(1):497-509.

47. Hobson KA, Fisk A, Karnovsky N, Holst M, Gagnon JM, Fortier MA. A stable isotope $\left(\delta^{13} \mathrm{C}, \delta^{15} \mathrm{~N}\right)$ model for the north water food web: Implications for evaluating trophodynamics and the flow of energy and contaminants. Deep-Sea Res II Top Stud Oceanogr. 2002;49(22-23):5131-5150. https://doi.org/10.1016/S09670645(02)00182-0

48. Logan JM, Lutcavage ME. A comparison of carbon and nitrogen stable isotope ratios of fish tissues following lipid extractions with non-polar and traditional chloroform/methanol solvent systems. Rapid Commun Mass Spectrom. 2008;22(7):1081-1086. https://doi.org/10.1002/ rcm.3471

49. Alamaru A, Yam R, Shemesh A, Loya Y. Trophic biology of Stylophora pistillata larvae: evidence from stable isotope analysis. Mar Ecol Prog Ser. 2009;383:85-94. https://doi.org/10.3354/meps07958

50. Cequier-Sánchez E, Rodríguez C, Ravelo ÁG, Zárate R. Dichloromethane as a solvent for lipid extraction and assessment of lipid classes and fatty acids from samples of different natures. J Agric Food Chem. 2008;56(12):4297-4303. https://doi.org/10.1021/ jf073471e

51. Mateo MA, Serrano O, Serrano L, Michener RH. Effects of sample preparation on stable isotope ratios of carbon and nitrogen in marine invertebrates: Implications for food web studies using stable isotopes. Oecologia. 2008;157(1):105-115. https://doi.org/10.1007/ s00442-008-1052-8

52. Bunn SE, Loneragan NR, Kempster MA. Effects of acid washing on stable isotope ratios of $\mathrm{C}$ and $\mathrm{N}$ in penaeid shrimp and seagrass: Implications for food-web studies using multiple stable isotopes. Limnol Oceanogr. 1995;40(3):622-625.

53. Kennedy P, Kennedy H, Papadimitriou S. The effect of acidification on the determination of organic carbon, total nitrogen and their stable isotopic composition in algae and marine sediment. Rapid Commun Mass Spectrom. 2005;19(8):1063-1068. https://doi.org/10.1002/ rcm.1889

54. Søreide JE, Tamelander T, Hop H, Hobson KA, Johansen I. Sample preparation effects on stable $\mathrm{C}$ and $\mathrm{N}$ isotope values: a comparison of methods in Arctic marine food web studies. Mar Ecol Prog Ser. 2006;328:17-28. https://doi.org/10.3354/meps328017

55. Loya Y. The Red Sea coral Stylophora pistillata is an $r$ strategist. Nature. 1976;259(5543):478-480.

56. Veron JEN. Corals of the world. 1-3 Australian Institute of Marine Science: Townsville, Australia; 2000.

57. Loya Y, Sakai K, Nakano Y, Woesik RV. Coral bleaching: the winners and the losers. Ecol Lett. 2001;4(2):122-131. https://doi.org/ 10.1046/j.1461-0248.2001.00203.x

58. Keshavmurthy S, Yang S-Y, Alamaru A, et al. DNA barcoding reveals the coral "laboratory-rat", Stylophora pistillata encompasses multiple identities. Sci Rep. 2013;3(1):1520. https://doi.org/10.1038/ srep01520

59. Jacob U, Mintenbeck K, Brey T, Knust R, Beyer K. Stable isotope food web studies: a case for standardized sample treatment. Mar Ecol Prog Ser. 2005;287:251-253. https://doi.org/10.3354/meps287251

60. Coplen TB. Guidelines and recommended terms for expression of stable-isotope-ratio and gas-ratio measurement results. Rapid Commun Mass Spectrom. 2011;25(17):2538-2560. https://doi.org/ 10.1002/rcm.5129

61. Bessey C, Vanderklift MA. Drying method has no substantial effect on $\delta^{15} \mathrm{~N}$ or $\delta^{13} \mathrm{C}$ values of muscle tissue from teleost fishes. Rapid Commun Mass Spectrom. 2014;28(3):265-273. https://doi.org/ $10.1002 / \mathrm{rcm} .6780$

62. Akamatsu F, Suzuki Y, Kato Y, Yoshimizu C, Tayasu I. A comparison of freeze-drying and oven-drying preparation methods for bulk and compound-specific carbon stable isotope analyses: examples using the benthic macroinvertebrates Stenopsyche marmorata and Epeorus latifolium. Rapid Commun Mass Spectrom. 2016;30(1):137-142. https://doi.org/10.1002/rcm.7421

63. Bodin N, Le Loc'h F, Hily C. Effect of lipid removal on carbon and nitrogen stable isotope ratios in crustacean tissues. J Exp Mar Biol Ecol. 2007;341(2):168-175. https://doi.org/10.1016/j.jembe. 2006.09.008

64. Post DM, Layman CA, Arrington DA, Takimoto G, Quattrochi J, Montaña CG. Getting to the fat of the matter: models, methods and assumptions for dealing with lipids in stable isotope analyses. Oecologia. 2007;152(1):179-189. https://doi.org/10.1007/s00442006-0630-x

65. Sweeting CJ, Polunin NVC, Jennings S. Effects of chemical lipid extraction and arithmetic lipid correction on stable isotope ratios of fish tissues. Rapid Commun Mass Spectrom. 2006;20(4):595-601. https://doi.org/10.1002/rcm.2347

66. Pinnegar JK, Polunin NVC. Differential fractionation of $\delta^{13} \mathrm{C}$ and $\delta^{15} \mathrm{~N}$ among fish tissues: Implications for the study of trophic interactions. Funct Ecol. 1999;13(2):225-231. https://doi.org/10.1046/j.13652435.1999.00301.x

67. Leuzinger S, Anthony KRN, Willis BL. Reproductive energy investment in corals: scaling with module size. Oecologia. 2003;136(4):524-531. https://doi.org/10.1007/s00442-003-1305-5

68. Dai CF, Soong K, Fan TY. Sexual reproduction of corals in northern and southern Taiwan. Proc 7th Intl Coral Reef Symp. 1992;1:448-455.

69. Bouillon S, Raman AV, Dauby P, Dehairs F. Carbon and nitrogen stable isotope ratios of subtidal benthic invertebrates in an 
estuarine mangrove ecosystem (Andhra Pradesh, India). Estuar Coast Shelf Sci. 2002;54(5):901-913. https://doi.org/10.1006/ ecss.2001.0864

70. Kang C-K, Kim JB, Lee KS, Kim JB, Lee P-Y, Hong J-S. Trophic importance of benthic microalgae to macrozoobenthos in coastal bay systems in Korea: dual stable $\mathrm{C}$ and $\mathrm{N}$ isotope analyses. Mar Ecol Prog Ser. 2003;259:79-92. https://doi.org/10.3354/ meps259079

71. Stoner AW, Zimmerman RJ. Food pathways associated with penaeid shrimps in a mangrove-fringed estuary. Fish Bull. 1988;86:543-552.

\section{SUPPORTING INFORMATION}

Additional supporting information may be found online in the Supporting Information section at the end of the article.

How to cite this article: Sturaro N, Hsieh YE, Chen Q, Wang P-L, Denis V. Toward a standardised protocol for the stable isotope analysis of scleractinian corals. Rapid Commun Mass Spectrom. 2020;34:e8663. https://doi.org/10.1002/rcm.8663 